\title{
Biochemical and bioactive phytonutrients changes in tissues of two cultivars of fresh-cut cassava in stick form under refrigerated storage
}

\author{
Alterações bioquímicas e em fitonutrientes bioativos em tecidos de duas cultivares \\ de mandioca minimamente processadas no formato palito, armazenadas sob refrigeração
}

\author{
Mateus da Silva Junqueira ${ }^{I}$ Adriano do Nascimento SimõesII \\ Tocio Sediyama ${ }^{\text {III }}$ Paulo Cesar Côrrea ${ }^{\text {IV }}$ Rolf PuschmannV $^{V}$
}

\begin{abstract}
The aim of this study was to evaluate the effects of fresh-cut in stick form of two cassava cultivars on their biochemical and antioxidant characteristics, at two harvest times. The fresh cut cassava sticks were packaged in polypropylene, maintained at $5 \pm 1^{\circ} \mathrm{C}$, with $90 \pm 5 \%$ relative humidity for 12 days. The concentration of carotenoids, total soluble phenolic compounds and the activity of phenylalanine ammonia lyase and antioxidant capacity were significantly higher for the sticks of cultivar 'Amarela' cassava than for the sticks of cultivar 'Cacau'. The concentrations of carotenoids, total soluble phenolic compounds, and the activity of phenylalanine ammonia lyase and antioxidant capacity were all significantly greater when harvested at 14-month of age. There was a significant increase in the activity of phenylalanine ammonia lyase during the 12 days of storage at $5^{\circ} \mathrm{C}$. However, there was a decrease in total carotenoids, soluble phenolic compounds, and in the antioxidant capacity of the two cultivars.
\end{abstract}

Key words: Manihot esculenta Crantz, carotenoids, PAL, quality, antioxidant capacity.

\section{RESUMO}

Objetivou-se avaliar, em duas cultivares de mandioca, o efeito do processamento mínimo no formato palito sobre características bioquímicas, em duas idades de colheita. Os palitos de mandioca minimamente processados foram acondicionados em embalagens de polipropileno, a $5 \pm 1^{\circ} \mathrm{C}, 90 \pm 5 \%$ de umidade relativa, por 12 dias. $O$ teor de carotenoides, e de compostos fenólicos solúveis foram significativamente maiores para os palitos da cultivar 'Amarela' do que para a cultivar 'Cacau', assim como a atividade da fenilalanina amônia liase e a capacidade antioxidante. $\mathrm{O}$ teor de carotenoides totais e compostos fenólicos solúveis, assim como a atividade da fenilalanina amônia liase e a capacidade antioxidante, foram superiores quando colhidas aos 14 meses. Houve acréscimo na atividade da fenilalanina amônia liase durante os 12 dias de conservação a $5^{\circ} \mathrm{C}$, no entanto, houve decréscimo para o teor de carotenoides totais e de compostos fenólicos solúveis, assim como da capacidade antioxidante.

Palavras-chave: Manihot esculenta Crantz, carotenoides, PAL, qualidade, capacidade antioxidante.

\section{INTRODUCTION}

Interest in the role of antioxidant consumption, including carotenoids, ascorbate, tocopherols, and phenolic compounds in human health has led to agronomic studies on topics such as genetic improvement of cultivars, maturation point, harvest method and food science, along with postharvest, processing, and conservation methods. This aims to identify antioxidants in fruits and vegetables and to determine how their content and activity can be maintained or even improved (ALASALVAR et al., 2005; SIMÕES, 2007).

Peeling and cutting during the preparation of fresh-cut vegetables induces an increase in some physiological responses (ODRIOZOLA-SERRANO, 2008). In cassava, this handling may induce an alteration in the metabolism of phenylpropanoids and cause browning, resulting in a loss in quality (BUSCHMANN et al., 2000). On the other hand,

\footnotetext{
IDepartamento de Engenharia de Alimentos, Universidade Federal de São João Del Rei (UFSJ), CP 56, KM 47, 35701-970, Sete Lagoas,

MG, Brasil. E-mail: mateusjunq@yahoo.com.br. Autor para correspondência.

"Universidade Federal Rural de Pernambuco (UFRPE), Serra Talhada, PE, Brasil.

IIIDepartamento de Fitotecnia, Universidade Federal de Viçosa (UFV), Viçosa, MG, Brasil.

${ }^{\mathrm{IV}}$ Departamento de Engenharia Agrícola, UFV, Viçosa, MG, Brasil.

${ }^{\vee}$ Departamento de Fisiologia Vegetal, UFV, Viçosa, MG, Brasil.
} 
phenolic compounds may protect the cell constituents against oxidative damage, thereby limiting the risk of developing various degenerative diseases associated with oxidative stress (SCALBERT, 2005; PADDA \& PICHA, 2008).

According to FUKUDA \& BORGES (1990) and NGEVE (2003), the harvest age and cultivars may influence the quality and composition of the raw material, and after 12 months the cassava roots can lose quality. Yellow cassavas naturally possess more carotenoids than white cassavas (OLIVEIRA, 2006). The antioxidant property of the carotenoid pigments in the roots of yellow cassava may delay the deterioration in whole roots, which possibly prolongs its useful life (SASSON, 2004) compared to white pulp cultivars.

The benefits of the new minimal processing technique for cassava sticks could also meet the need for a convenient food. Thus, the inherent differences in the carotenoid content of the two cultivars in this study possibly may be reflected in foods with different antioxidant potentials

Therefore, the aim of this study is to evaluate biochemical and bioactive phytonutrients changes in two cultivars of fresh cut cassava in stick form, stored under refrigeration.

\section{MATERIAL AND METHODS}

Cassava (Manihot esculenta Crantz) plants of the Cacau (white pulp) and Amarela (yellow pulp) cultivars were produced by a Viçosa-MG (Brazil) producer (geographical position: Latitude: $20^{\circ} 45^{\prime}$ 14" S, Longitude: $42^{\circ} 52^{\prime} 55^{\prime} \mathrm{W}$ ) and harvested in 2009. They were harvested 12 and 14 months after planting, respectively. After harvest, the roots were placed in plastic boxes and transported to the Minimal Processing Unit (Unidade de Processamento Mínimo) of the Universidade Federal de Viçosa-UFV.

The cassava roots were standardized by size, and roots that exhibited attacks by pathogens or pests were discarded. The selected roots were washed with running water to eliminate dirt from the field and were sanitized in a $200 \mathrm{mgL}^{-1}$ chlorine solution (Sodium Dichloro-S-Triazinetrione) in water at $5 \pm 2{ }^{\circ} \mathrm{C}$ for 10 minutes. Then, were divided into pieces of approximately $5 \mathrm{~cm}$ in length, immediately placed in water at $5 \pm 2{ }^{\circ} \mathrm{C}$, and subsequently manually peeled and cut into sticks using a mechanical cutter (JUNQUEIRA, 2009).

The cassava sticks were immersed in water containing $200 \mathrm{mgL}^{-1}$ chlorine (Sodium Dichloro-STriazinetrione) at $5 \pm 2{ }^{\circ} \mathrm{C}$ for ten minutes. They were then rinsed by immersion in water containing $3 \mathrm{mgL}^{-1}$ chlorine at $5 \pm 2^{\circ} \mathrm{C}$ for 10 minutes. The sticks were centrifuged using a stainless steel centrifuge for 10 seconds with a force of $160 \mathrm{~g}$.

Samples of $200 \mathrm{~g}$ of cassava sticks were placed in polypropylene bags of approximately $60 \mu \mathrm{m}$ in thickness measuring $10 \mathrm{~cm} \times 15 \mathrm{~cm}$. These were kept refrigerated at $5 \pm 1^{\circ} \mathrm{C}$ for a period of 12 days and analyzed biochemically every three days.

The total carotenoids ( $\mu \mathrm{g}$ carotenoids $\left.\mathrm{g}^{-1} \quad \mathrm{FW}\right)$ were extracted as described by LICHTENTHALER (1987). The PAL extraction and assaying ( $\triangle \mathrm{ABS} \mathrm{h}^{-1} \mathrm{~g}^{-1} \mathrm{FW}$ ) were performed according to methods described by KE \& SALTVEIT (1986) and the phenolic compounds (mM galic acid $\mathrm{g}^{-1} \mathrm{FW}$ ) were extracted and quantified as described by REYES et al. (2007).

The antioxidant capacity ( $\%$ RQA) of the extract used for quantification of the phenolic compounds was determined by the capacity to sequester the free radical 2,2-diphenyl-1picrylhydrazyl (DPPH) according to the method described by BRAND-WILLIAMS et al. (1995), modified by MILIAUSKAS et al. (2004), and adapted for cassava.

One $0.2-\mathrm{mL}$ aliquot of the methanol extract was added to $3.8 \mathrm{~mL}$ of a solution of $112 \mathrm{mM}$ DPPH in a test tube. The mixture was shaken in a tube agitator and allowed to react for 30 minutes in the dark. Absorbance at $515 \mathrm{~nm}$ was read with a spectrophotometer. The $112 \mathrm{mM}$ DPPH solution with $200 \mu 1$ of methanol was used as a control.

The antioxidant capacity was expressed as the Radical Quenching Activity (\% RQA), calculated as: \% RQA $=(($ control ABS - sample ABS)/control ABS) $x 100$, in which ABS is the mean absorbance at $515 \mathrm{~nm}$.

The experiment design was completely randomized, with four repetitions, in a $2 \times 2 \times 5$ factorial layout, with two cultivars, two harvest times and five observation times. Each experimental unit was made up of $200 \mathrm{~g}$ of fresh-cut and packaged cassava. The data were subjected to analysis of 
variance and the averages of the cultivars and harvest times and their interactions were compared with an $\mathrm{F}$ test at 5\% significance. A regression analysis at 5\% significance was performed to compare the different storage times. Statistical analysis was performed with SAEG program - Statistical Analysis System and Genetics (2007). To evaluate the association between the content of soluble phenolic compounds with antioxidant capacity, it was used the Pearson Correlation Coefficient.

\section{RESULTS AND DISCUSSION}

Total carotenoids was statistically different to cultivar, harvest time and storage time (Figure 1). The concentration of total carotenoids was significantly greater in the sticks of the Amarela cassava cultivar $\left(10-12 \mu \mathrm{g} \mathrm{g}^{-1} \mathrm{FW}\right)$ than in the sticks of the 'Cacau' cultivar $\left(5-7 \mu \mathrm{g} \mathrm{g}^{-1} \mathrm{FW}\right)$ at both harvest times, according the $\mathrm{F}$ test (Figure 1), as well as observed by KIMURA et al. (2007) and CHAMPAGNE et al. (2010). This indicates that the 'Amarela' cultivar has almost double the amount of total carotenoids than the white cultivar. However, the content of carotenoids significance decreases during storage, according the regression test. The concentration of carotenoids in roots of more than 1700 clones of whole cassava in the Americas varied from 1.02 to $10.4 \mu \mathrm{g} \mathrm{g}^{-1} \mathrm{FW}$ (CHÁVEZ et al., 2005).

There was significance difference in carotenoid content between the harvest ages for both cultivars, confirmed by $\mathrm{F}$ test, yet the carotenoid concentration significantly decreased during entire period of refrigerated storage, according the regression test (Figure 1). KIMURA et al. (2007) also observed a decrease of the concentration of carotenoids during storage. The degradation of carotenoids may have occurred due to the oxidative stress suffered by cassava as a function of tissue exposure to oxygen, due to cut into stick form (REILLY et al, 2003; CHAVEZ et al, 2007).

PAL activity was statistically different to cultivar, harvest time and storage time (Figure 2). The PAL activity was significantly greater in the sticks of the Amarela cassava cultivar $\left(0,14-0,24 \Delta\right.$ ABS $h^{-1} \mathrm{~g}^{-1}$ FW) than in the sticks of the 'Cacau' cultivar $(0,06-$

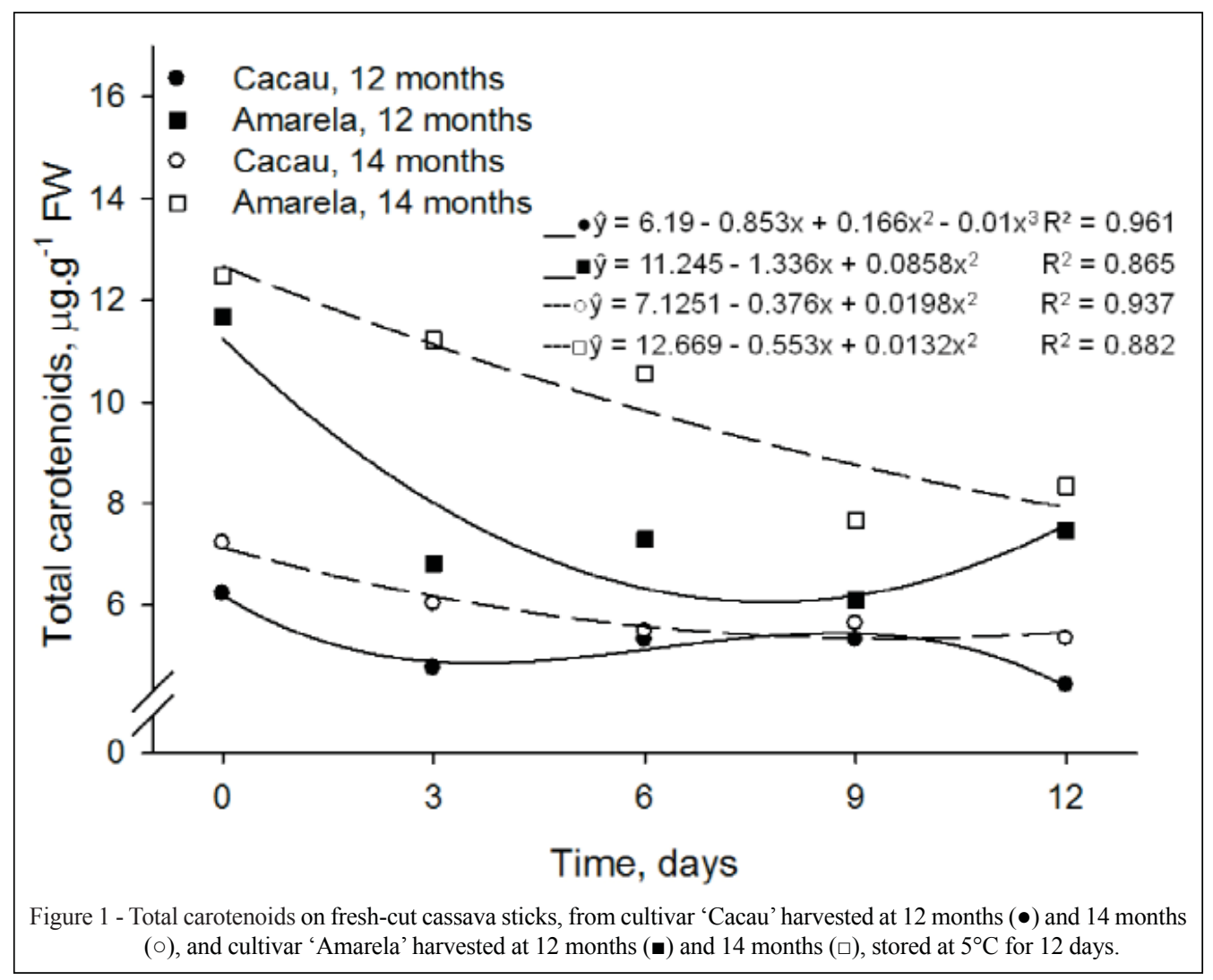

Ciência Rural, v.44, n.7, jul, 2014. 


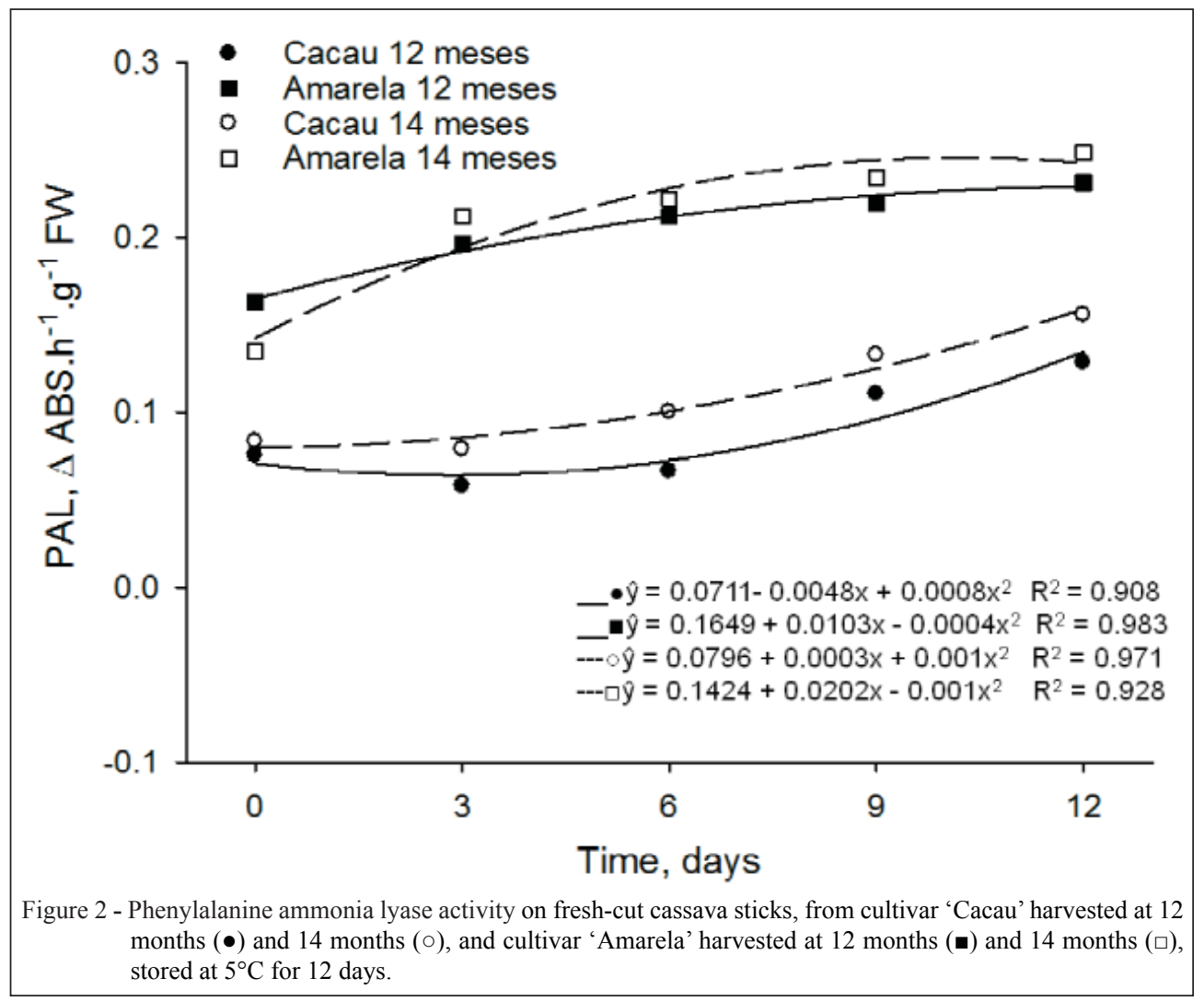

$\left.0,14 \triangle \mathrm{ABS} \mathrm{h}^{-1} \mathrm{~g}^{-1} \mathrm{FW}\right)$ at both harvest times, confirmed by $\mathrm{F}$ test (Figure 2). However, the PAL activity increases during the storage period, according the regression test. The same behavior was also observed in the studies by RICKARD (1985), PLUMBLEY \& RICKARD (1991) and MEDEIROS (2009).

The increased synthesis of PAL is an expected response in fresh-cut products, such as shear response to cutting (CAMPOS-VARGAS et al., 2005), since the PAL is a key enzyme in the synthesis of phenolic compounds involved in the response system to injury (HAHLBROCK \& SCHEEL, 1989). This increase is consistent with the studies of REYES et al. (2007), who found an increase in PAL activity after the cutting of various products, including carrots, potatoes, and sweet potatoes.

Phenolic compounds are considered important antioxidants that may help to prevent many human chronic diseases (PADDA \& PICHA, 2007). The concentration of total soluble phenolic compounds was statistically different to cultivar, harvest time and storage time (Figure 3). It was found higher content of phenolic compounds in 'Amarela' cultivar $(0.31 \mathrm{mM}$ galic acid $\left.\mathrm{g}^{-1} \mathrm{FW}\right)$ than in cultivar 'Cacau' $(0.24 \mathrm{mM}$ galic acid $\mathrm{g}^{-1} \mathrm{FW}$ ), according the $\mathrm{F}$ test (Figure 3 ). The concentration of phenols was also significantly higher in the cassava sticks harvested at 14 months than those harvested at 12 months, according F test, of encounter with the results found by BOONSENG et al. (1999). In addition, the concentration of soluble phenols during refrigerated storage decreased in both cultivars, confirmed by the regression test. CANTO (2011) also found a decrease in two cassava cultivars (yellow and white pulp) during storage, however, the cultivar yellow pulp exhibited lower levels of phenolics.

BUSCHMANN et al. (2000) did not find any differences in the phenolic content in the slices of cassava stored at ambient temperature for 7 days.

The decrease in the concentration of phenols for cut potatoes and cabbage stored under refrigeration suggests that the phenols produced by PAL during cutting were preferentially diverted for the formation of insoluble phenols such as lignin and suberin, which are involved in the scarring of injured tissues (REYES et al., 2007) that could also be present in cassava. In addition, soluble phenols may have reacted with the free radicals formed during oxidative stress and acted as antioxidants (FERRARI, 2003). 


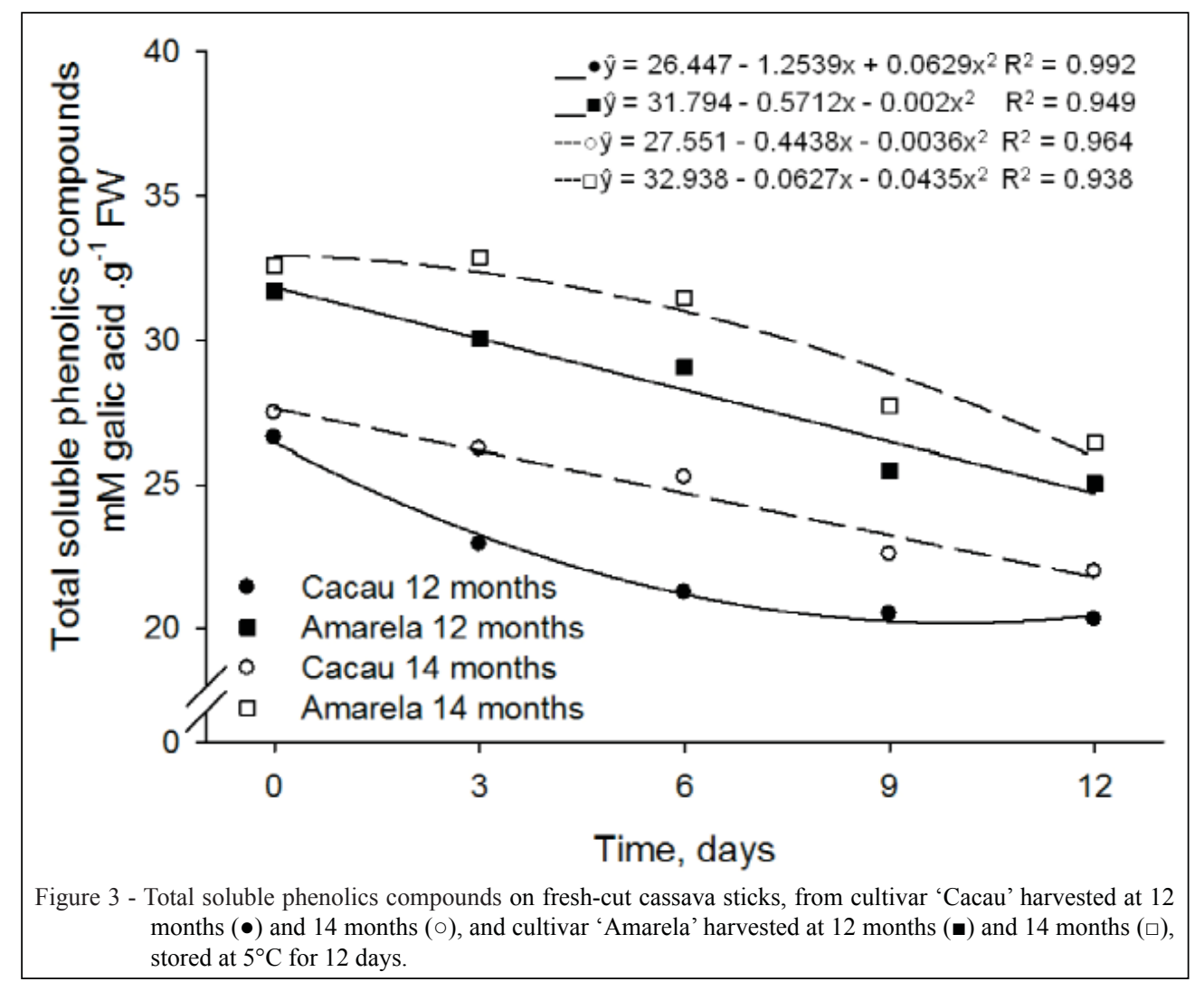

Sticks of the 'Amarela' cultivar maintained a significantly higher capacity to sequester radicals than those of the 'Cacau' cultivar throughout the storage period, according the $\mathrm{F}$ test. Sticks from cassava harvested at 14 months also had greater antioxidant capacity than sticks from cassava harvested at 12 months, according the F test (Figure 4). The antioxidant capacity, quantified by the capacity to sequester radicals, exhibited a decrease during refrigerated storage, independent of the cultivar analyzed, confirmed by the regression test (Figure 4).

It was found that the association between the soluble phenolic compounds and the antioxidant capacity exhibited $\mathrm{r}=0.959$, which describes a strong positive correlation $(0.8<\mathrm{r}<1)$ in accordance with the concepts of the Pearson correlation coefficient as well as being statistically significant. SPAGOLLA et.al. (2009) also found strong positive correlation between phenolics and antioxidant capacity in the blueberry fruit, even as BERNARDES et al. (2011) found in the kiwi fruit.

The antioxidant capacity of the cassava roots is largely due to phenolic compounds, which is consistent with the profile of total soluble phenols
(BUSCHMANN et al., 2000), which also decreased during the period of refrigerated storage.

\section{CONCLUSION}

The concentration of total carotenoids and soluble phenolic compounds, as well as the activity of phenylalanine ammonia lyase and the antioxidant capacity, were greater when samples harvested at 14 months.

Fresh-cut cassava sticks of the Amarela cultivar exhibit different functional characteristics than sticks of the 'Cacau' cultivar, such as a greater concentration of total carotenoids, and total soluble phenols, which led to increases the total antioxidant activity of the product. However, these characteristics decreased significantly throughout storage in both cultivars.

\section{ACKNOWLEDGMENTS}

To Conselho Nacional de Desenvolvimento Científico e Tecnológico (CNPq), Coordenação de Aperfeiçoamento de Pessoal de Nível Superior (Capes) and Fundação de Amparo à Pesquisa do estado de Minas Gerais (FAPEMIG). 


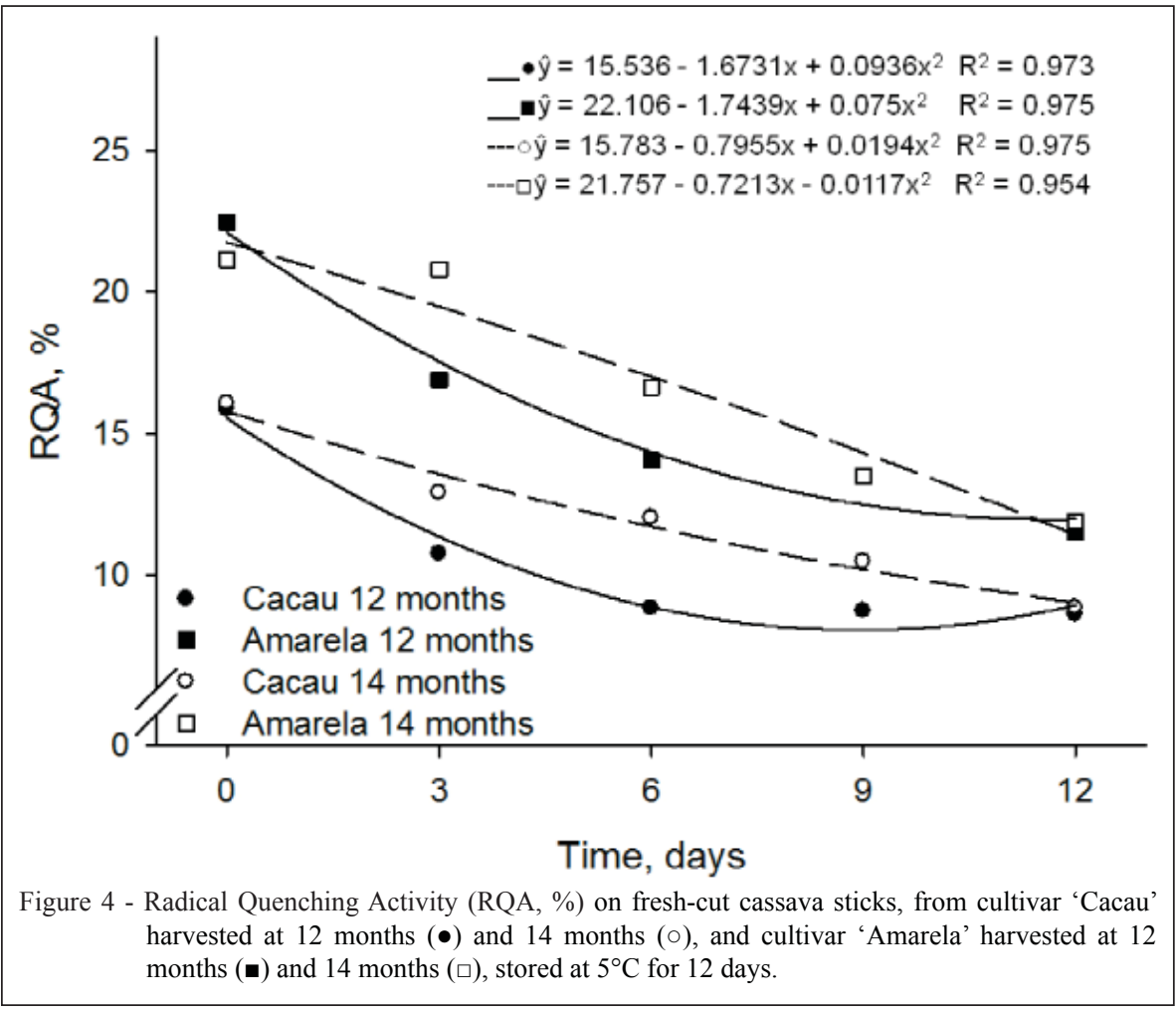

\section{REFERENCES}

ALASALVAR, C. et al. Effect of chill storage and modified atmosphere packaging (MAP) on antioxidant activity, anthocyanins, carotenoids, phenolics and sensory quality of readyto-eat shredded orange and purple carrots. Food Chemistry, v.89, p.69-76, 2005. Avaiable from: <http://www.sciencedirect.com/ science/article/pii/S0308814604001736>. Accessed: Feb. 15, 2010. doi:10.1016/j.foodchem.2004.02.013.

BERNARDES, N.R. Atividade antioxidante e fenois totais de frutas de Campos dos Goytacazes RJ. Perspectivas Online, v.1, p.53-59, 2011. Avaiable from: <http://www.seer.perspectivasonline.com.br/ index.php/CBS/article/view/16/5>. Accessed: Oct. 16, 2012.

BOONSENG, O. et. al. Effect of planting seasons, varieties and harvesting times on biochemical properties of cassava (Manihot esculenta Crantz) roots. Kasetsart Journal Nature Sciences, v.33, p. 497-506, 1999. Avaiable from: <http://research.rdi.ku.ac. th/world/showItem.php?itemID=116116\&lang=en $>$. Accessed: Nov. 03, 2012.

BRAND-WILLIAMS, W. et al. Use of a free radical method to evaluate antioxidant activity. Food Science and Technology, v.28, p.25-30, 1995.

BUSCHMANN, H. et al.Hydrogen peroxide and Flavan-3-ols in storage roots of cassava during postharvest deterioration. Journal of Agriculture and Food Chemistry, v.48, p.55225529, 2000. Avaiable from: <http://www.ncbi.nlm.nih.gov/ pubmed/11087513>. Accessed: Mar.26, 2009.

CAMPOS-VARGAS, R. et al. Heat shock treatments delay the increase in wound-induced phenylalanine ammonia-lyase activity by altering its expression, not its induction in Romaine lettuce (Lactuca sativa) tissue. Physiology Plantarum, v.123, p.82-91, 2005. Avaiable from: <http://onlinelibrary.wiley.com/doi/10.1111/ j.1399-3054.2005.00446.x/abstract>. Accessed: Mar. 20, 2009.doi: 10.1111/j.1399-3054.2005.00446.x.

CANTO, A.R. Alterações químicas e histológicas em raízes de mandioca (Manihot esculenta Crantz) armazenadas das cultivares Catarina amarela e Catarina branca. 2011. 86p. Dissertação (Mestrado em Ciência dos Alimentos) - Universidade Estadual de Londrina, PR.

CHAMPAGNE, A. et. al. Carotenoid profiling of tropical root crop chemotypes from Vanuatu, South Pacific. Journal of Food Composition and Analysis, v.23, p.763-771, 2010. Avaiable from: <http://www. sciencedirect.com/science/article/pii/S0889157510001687>. Accessed: Oct. 22, 2012.doi: 10.1016/j.jfca.2010.03.021.

CHAVEZ, A.L. et al. Retention of carotenoids in cassava roots submitted to different processing methods. Journal of Science Food and Agriculture, v.87, p.388-393, 2007. Avaiable from: $<$ http://onlinelibrary.wiley.com/doi/10.1002/jsfa.2704/pdf $>$. Accessed: Feb. 22, 2013.

CHÁVEZ, A.L. et al. Variation of quality traits in cassava roots evaluated in landraces and improved clones. Euphytica, v.143, p.125-133, 2005. Available from: <http://www.springerlink.com/ content/r5q4n8072574m7g8/>. Accessed: Mar. 21, 2008.

FERRARI, C.K.B.; TORRES, E.A.F.S. Biochemical pharmacology of functional foods and prevention of chronic diseases of aging. Biomedicine \& Pharmacotherapy, v.57, p.251-260, 2003.Available from: <http:/www.ncbi.nlm.nih.gov/ pubmed/12888262>. Accessed: Jan. 11, 2009.

Ciência Rural, v.44, n.7, jul, 2014. 
FUKUDA, W.M.G.; BORGES, M.F. Influência da idade de colheita sobre a qualidade de raízes em diferentes cultivares de mandioca de mesa. Revista Brasileira de Mandioca, v.9, p.7-19, 1990.

HAHLBROCK, K.; SCHEEL, O. Physiology and molecular biology of phenyl propanoid metabolism. Annual Review of Plant Physiology, v.40, p.347-369, 1989. Available from: $<$ http://www.annualreviews.org/doi/abs/10.1146/annurev. pp.40.060189.002023>. Accessed: Mar. 17, 2008. doi:10.1146/ annurev.pp.40.060189.002023.

JUNQUEIRA, M.S. Caracterização de mandioca minimamente processada no formato 'palito'. 2009.68f. Thesis (Plant Physiology Doctoral) - Course of Plant Physiology, Universidade Federal de Viçosa, MG.

KE, D.; SALTVEIT, M.E. Effects of calcium and auxin on russet spotting and phenylalanine ammonia-lyase activity in iceberg lettuce. HortScience, v.5, p.1169-1171, 1986.

KIMURA, M. et al. Screening and HPLC methods for carotenoids in sweetpotato, cassava and maize for plant breeding trials. Food Chemistry, v.100, p.1734-1746, 2007. Available from: <http:// www.sciencedirect.com/science/article/pii/S0308814605009180>. Acessed: Jan. 23, 2009.doi: 10.1016/j.foodchem.2005.10.020.

LICHTENTHALER, H.K. Chlorophylls and carotenoids: pigment photosynthetic biomembranes. Methods Enzymology, v.148, p.362-385, 1987.

MEDEIROS, E.A.A. Deterioração pós-colheita da mandioca minimamente processada. 2009. 101f. Thesis (Plant Physiology Doctoral) - Course of Plant Physiology - Universidade Federal de Viçosa, MG.

MILIAUSKAS, G.et al. Screening of radical scavenging activity of some medicinal and aromatic plants. Food Chemistry, v.85, p.231-237, 2004. Available from: <http://www.sciencedirect. com/science/article/pii/S0308814603003492>. Accessed: Jun. 27, 2009. doi: http://dx.doi.org/10.1016/j.foodchem.2003.05.007.

NGEVE, J.M. Cassava root yields and culinary qualities as affected by harvest age and test environment. Journal of Science Food and Agriculture, v.83, p.249-257, 2003. Available from: $<$ http://onlinelibrary.wiley.com/doi/10.1002/jsfa.1307/abstract $>$. Accessed: Oct. 25, 2012. doi: /10.1002/jsfa.1307.

ODRIOZOLA-SERRANO, I. et al. Effect of minimal processing on bioactive compounds and color attributes of fresh-cut tomatoes. LWT - Food Science and Technology, v.41, p.217-226, 2008. Available from: <http://www.sciencedirect.com/science/article/ pii/S0023643807001168>. Accessed: Jul. 16, 2008.doi: 10.1016/j. lwt.2007.03.002

OLIVEIRA, A.R.G. Avaliação e estudo da retenção de carotenoides totais e $\beta$-Caroteno em mandioca amarela mansa e brava. 2006. 61f. Dissertation (Master Degree) - Course of Food
Science and Technology, Universidade Federal Rural do Rio de Janeiro, RJ.

PADDA, M.S.; PICHA, D.H. Antioxidant activity and phenolic composition in 'beauregard' sweetpotato are affected by root size and leaf age. Journal of American Society Horticulture Science, v.132, p.447-451, 2007. Avaiable from: <http://journal.ashspublications.org/ content/132/4/447.full>. Accessed: Oct. 23, 2012.

PADDA, M.S.; PICHA, D.H. Effect of low temperature storage on phenolic composition and antioxidant activity of sweetpotatoes. Postharvest Biology and Technology, v.47, p.176-180, 2008. Avaiable from: <http://www.sciencedirect.com/science/article/pii/ S092552140700213X>. Accessed: May, 12, 2009. doi: 10.1016/j. postharvbio.2007.06.014.

PLUMBLEY, R.A.; RICKARD, J.E. Post-harvest deterioration of cassava. Tropical Science, v.31, p.295-303, 1991.

REILLY, K. et al. Oxidative stress responses during cassava post-harvest physiological deterioration. Plant Molecular Biology, v.53, p.669-685, 2003. Avaiable from: <www.isb.vt.edu/ news/2012/Aug/Zidenga.pdf>. Acessed: Feb. 25, 2013.

REYES, L.F. et al. The increase in antioxidant capacity after wounding depends on the type of fruit or vegetable tissue. Food Chemistry, v.101, p.1254-1262, 2007. Avaiable from: <http:// www.sciencedirect.com/science/article/pii/S0308814606002603>. Acessed: May, 12, 2009. doi: 10.1016/j.foodchem.2006.03.032.

RICKARD, J.E. Physiological deterioration of cassava roots. Journal of the Science of Food and Agriculture, v.36, p.167$176,1985$.

SAEG (STATISTICAL ANALYSIS SYSTEM AND GENETICS). SOFTWARE 9.1 version. Viçosa: UFV/FUNARBE, 2007.

SASSON, A. Biotechnologies: current achievements and prospects social acceptance of biotechnology-derived products. 2004. $157 \mathrm{p}$. France. Available from: <http://www.europabio.org/documents/ monograph1-HC.pdf>. Accessed: Jun. 17, 2012.

SCALBERT, A. et al. Dietary polyphenols and the prevention of diseases. Critical Reviews in Food Science and Nutrition, v.45, p.287-306, 2005. Avaiable from: <http://www.ncbi.nlm.nih.gov/ pubmed/16047496>. Accessed: Sept. 25, 2009

SIMÕES, A.N. et al. Estratégias para reduzir o estresse do processamento mínimo. Visão Agrícola, v.4, p.92-96, 2007. Avaiable from: $<$ http://www.esalq.usp.br/visaoagricola/edicoes/07. html>. Accessed: Mar. 06, 2009.

SPAGOLLA, L.C. et. al. Extração alcoólica de fenólicos e flavonóides totais de mirtilo "Rabbiteye" (Vacciniumashei) e sua atividade antioxidante. Revista Ciência Farmaceutica Básica Aplicada, v.30, p.187-191, 2009. Avaiable from: <http:// serv-bib.fcfar.unesp.br/seer/index.php/Cien_Farm/article/ viewFile/535/823>. Accessed: Oct. 21, 2012. 